\title{
ISOLATION OF CAMPYLOBACTER JEJUNI FROM POULTRY CARCASSES
}

\author{
Abd El-Khallk, A. A. El-Shafle, A. A. M. and Mona, T. Raslan \\ Animal Health Research Instltule (Zagazlg Lab. Branch)
}

\begin{abstract}
The objective of this study was to assess the incidence of Campylobacter in broller carcasses and it was carried out on collection of 100 carcasses from a chicken abattotr. Eight bacterial agents $8 \%$ which proved morphologically and biochemically to be C. jejuni were recovered. Campylobacter Jejuni isolates were biotyped as biotype 1/4 Lsolates) biotype la ( 3 isolates) and biotype 2 (1 isolates. The level of Campylobacter jejuni in broiler carcasses was ranging from $1.9 \times 10$ to $3.31 \times 10 \mathrm{CFU}$ per igm of carcass. This study was done to evaluate the presence of $C$. Jejuni and identfy these bacteria in the processing line of chicken abattoirs. C. jejuni reststance was increased against some antibiotics as Ampicillin, colestin, Neorrycin, axytetracycline and Novobiocine.
\end{abstract}

\section{INTRODUCTION}

Campylobacter is a common rood-borne pathogen of humans that has been assoclated with poultry carcasses and further processed poultry products (White et al., 1997 and $8 a$ leha et al., 1998). It is generally thought that Campylobacter nows into commerclal proeessIng facilities on and within the llve birds and disseminated during the vartous processing procedures (Saleha et al., 1908).

Campylobacter can be recovered from broilcr carcasscs prior to entering the scald tank or by rinsing feathered carcasses (Stern et al., 1995), or by exclsing or swabbing the skin (Izat et al., 1998 and Kotula and Pandya 1895).

Despitc the presence of Campylobaeter on the outside of brollers. emphasis is commonly on the presenee and level of Campylobacter and other human pathogens in the alimentary tract. This interest is fueled by the concern the ruptured organs. such as crop or eeca may spill eontents rich in Campylobaeter onto the carcass. It was reported that the erop can be broken during processing (Hargls et al. 1995).

Byrd et al., (1988) reported that Campylobacter is evident In the majorlty (62\%) of erop samples examined on the rarm just prlor to catching and transport to plant. Oosterom et a.. (1983) found that Campylobacter is commonly recovered in high numbers. more than $\log 106.0 \mathrm{cfu} / \mathrm{g}$ in eeca and colon. Campylobaeter had also becn found on carcass skin samples. Berndtson et al., (1992) found 89\% of skdn samples form proeessed careasses were posituve for Campylobacter at about $\log 103.0 \mathrm{CFU} / g$ lower than that found in Intcstine sasnples (Oosterom et al., 1983 and Musgrove et al., 1997). However. Kotula and 
Pandya (1995) recorded high levels of Carnpylobacter on defeathered skln prior to scalding. breast skin had higher Campylobacler populations $(\log 106.9 \mathrm{cfu} / \mathrm{g})$ than did drum or thigh skln.

\section{MATERIAL AND METHODS}

\section{(I) Sampllag of broller carcasses:}

Each one whole carcasses per slaughler batch was collected aftcr chilling but belore processing. Avoid cross-contaminatlon during collectlon and transport of the carcasses. The carcasses were plaeed in separale sterile plastic bags to avold cross eontamination. Samples were kepl at 2 to $8^{\circ} \mathrm{C}$.

\section{(U) Sample preparation:}

Avold fat and $27 \mathrm{~g}$ lested prolein were taken and placed Into an empty Petri dish and further on in a stomacher bag.

About 27g tested protein were transferred Into nine volumes (abou $(243 \mathrm{ml}$ ) bullered peptone water (BPW) brought to room tcmperalure belore adding.

(III) Isolation and tdentification of Campylobacter organism:

$1 \mathrm{ml}$ of suspension was transferred to $9 \mathrm{ml}$ (thioglycolate broth), each sample was incubated at $37^{\circ} \mathrm{C}$ for 24 hours, examined for Campylubacler growth. The suspention was Investigated for detection of Campylobacter organisms as follows.

(1) Microscopical examination (Smibert, 1978):

A loopful form the suspected growth was taken and put on clean slides and covered with cover slips. These smears were examined under the phase contrast mieroscope using 400 magnifications for detectlon of the characteristic motility and morphology of Campylobacter organism.
(2) Irolntion procedures (Smlbert 1978):

In thls method. 2 loopluls of suspected growth were suspended in about $5 \mathrm{ml}$ of sterlle saline solution (pH 7.4) mixed well. then aspirated by sterlle syringe and $\mathrm{nl}$ tered through a Millipore niter of pore slze 0.65un (Sartonus Co. Polycarbonat fllter. Germany). The flrst few drops of the nltrate werc discarded, then one drop of remalnders were Inoculated onto the surface of well-dıed blood Brucella agar plates. The drop was let to be dried at $37^{\circ} \mathrm{C}$ for 30 minute, then streakcd onto the agar surlace. The plates were incubatcd at $37^{\circ} \mathrm{C}$ in microaerophlilic condiluon ( $5 \% \mathrm{Co}$ ).

(3) Bacteriological identification (Kwialck et al., 1990):

\subsection{Motility test:}

For moulity detection, a drop from the incubated enrichment thloglycollate broth was examined under phase-contrast microscope for motllity detection and $S$ shape character of campylobacter organisms.

\subsection{Colony characters and morphology:}

Sheep blood Brucella agar was used and suspected colonles of Campylobaeter organisms were stained by Gram's staln for stain. Ing afmnity and organism morphology.

\subsection{Oxygen requirement:}

Eaeh isolate was subcultured on two blood agar plates. One plate was Incubated aeroblcally and the other micro-aerophillic by using gas pack jar at $37^{\circ} \mathrm{C}$ and $42^{\circ} \mathrm{C}$ for $72 \mathrm{~h}$., then examined for growth.

\subsection{Blochemical identification:}

lsolates of Campylobacter were identlfled bloehemieally aceording to Carter, (1984).

(4) Sensituvity of Campylobacter 1solates to antlblotlcs was studled aeeording to Peckham, (1984). 


\section{RESULTS AND DISCUSSION}

The Incldence of Campylobacter infection in broller carcasses was carrled out by collection samples from 100 careasses among chicken abattolrs where its incidence was $8 \%$, while other Incidence percentage recorded were $12 \%$ by Bryan and Doyle (1995) and Berrang et al., (2001). The varlation in percentagcs espccially in high value due to the high contamination by Campylobacter in the processing plant where the linal results in contamination of the end product was about $49 \%$ and $80 \%$ respectlvely (Oosterom et al., 1983 and Roesenqulst et al., 2006).

\section{Campylobacter identification:}

Elght isolates were Identhed morphologically on culture basls as Campylobacter colonles were small, molst and transparent. Cover slide hanging drop methorl showed darting movement, Grain's stained preparatlons showed ncgativc curved rods and or splrals. Thcre wcre simllar result dcscribed by Levina, (1964) and Pckham, (1984).

The blochemical identification (Table 2) of 8 isolates showed no variation in biochemical activitics of $C$. Jejuni. Similar procedure was carricd out by Fletcher and Plastridge. (1964); Nell et al., (1984) and Ezzat et al., (1091). The obtained results showed that only 2 isolates wcre H2S negatlve using lead acctate strips. SImllar observatlons were reported by Fletcher and Plastidge (1984).

Biotyping of the Identlfied C. Jcjunl (Table 3) Isolates revealed 4 stralns of biotype 1, 3 strains blotype $1 \mathrm{a}$ and $\mathrm{l}$ straln belonged to blotype 2 . This was based on hlppurate hydroly- sis, DNA hydrolysis and H2S productlon. SImllar proeedures were carrled out by Lotr, (1984); Prescott and Bruln, (1981); Sm/bert (1878) and Adayel, (1993).

In Table (4), the presence and the level (from careasses) of Campylobacter were $B$ broiler carcasses from 100 broller carcasses being Campylobacter positive with number ranglng from $1.9 \times 10$ to $3.31 \times 10 \mathrm{CFU}$ per carcass. Similar results of Johannessen et al., (2007) which recorded that Campylobacter number were $2.6 \times 10$ CFU per carcass.

The antibingram to $C$. Jejunt isolates showed high sensitivity to Gcntamycin. Triincthobrim and Flumcquine. The high sens!tivity of the isolated C. Jejuni to Gentamycin was simllar to findings of Bradbury and Munroe (1985). Intermediate sensitlvity to $\mathrm{Ka}$ namycin and Carbenicilin were notleed to the isolatcd $C$. jejunl strains where they were sensitive to Kanamycin (Diker and Yardimci 1989). All the isolated strains wcre resistance to Arnpicillin and Colxacillin. Simllar results were obtalned by Zien (1989) and Ezzat et al., (1991).

\section{CONCLUSION}

It can conclude that the carcasses from Campylobacter positive broller ones were heavily contaminated with Campylobacter from cecal content. Carcasses might play an important role in the transmission of Campylobacter Jejunt to human being. These results emphasize the importance to improving control measures and both hygiene and sanitary condition in chicken abattoirs. 
Table (1): Culture characteristics of suspected Campylobacter isolates from broiler carcasses.

\begin{tabular}{|c|c|c|c|c|c|c|}
\hline \multirow{2}{*}{$\begin{array}{c}\text { Isolate } \\
\text { No. }\end{array}$} & \multicolumn{2}{|c|}{\begin{tabular}{c} 
Growth temperature \\
\cline { 2 - 7 }
\end{tabular}} & $\begin{array}{c}\text { Anaerobic } \\
\text { growth }\end{array}$ & $\begin{array}{c}\text { Growth in 5\% } \\
\text { oxygen }\end{array}$ & Motility \\
\hline \hline 12 & - & + & + & - & + & + \\
\hline 15 & - & + & + & - & + & + \\
\hline 20 & - & + & + & - & + & + \\
\hline 24 & - & + & + & - & + & + \\
\hline 43 & - & + & + & - & + & + \\
\hline 55 & - & + & + & - & + & + \\
\hline 73 & - & + & + & - & + & + \\
\hline 82 & - & + & + & - & + & + \\
\hline
\end{tabular}

Table (2): Biochemical identification of suspected Campylobacter isolates from broiler carcasses.

\begin{tabular}{|c|c|c|c|c|c|c|}
\hline $\begin{array}{c}\text { Isolate } \\
\text { No. }\end{array}$ & $\begin{array}{c}\text { Catalase } \\
\text { test }\end{array}$ & $\begin{array}{c}\text { Oxidase } \\
\text { test }\end{array}$ & $\begin{array}{c}\text { Glycine } \\
\text { tolerance }\end{array}$ & $\begin{array}{c}\text { Nacl } \\
\text { olerance } \\
3-5 \%\end{array}$ & $\begin{array}{c}\mathrm{H}_{2} \mathrm{~S} \\
\text { production on } \\
\text { lead acetate }\end{array}$ & $\begin{array}{c}\text { Hippurate } \\
\text { hydrolysis }\end{array}$ \\
\hline \hline 12 & + & + & + & - & + & + \\
\hline 15 & + & + & + & - & + & + \\
\hline 21 & + & + & + & - & - & + \\
\hline 24 & + & + & + & - & + & + \\
\hline 43 & + & + & + & - & + & + \\
\hline 55 & + & + & + & + & - & + \\
\hline 73 & + & + & + & - & + & + \\
\hline 82 & + & + & + & - & + & + \\
\hline
\end{tabular}


Table (3): Biotyping of $C$. jejuni isolates from broiler carcasses.

\begin{tabular}{|c|c|c|c|c|c|c|}
\hline $\begin{array}{c}\text { Case } \\
\text { No. }\end{array}$ & $\begin{array}{c}\text { Hippurate } \\
\text { hydrolysis }\end{array}$ & $\begin{array}{c}\text { Rapid } \\
\mathrm{H}_{2} \text { S test }\end{array}$ & $\begin{array}{c}\text { DNA } \\
\text { hydrolysis }\end{array}$ & $\begin{array}{c}\text { Biotypte } \\
1\end{array}$ & $\begin{array}{c}\text { Biotype } \\
\text { Ia }\end{array}$ & $\begin{array}{c}\text { Biotype } \\
2\end{array}$ \\
\hline 12 & + & - & + & & $1 \mathrm{a}$ & \\
\hline 15 & + & - & - & & & 2 \\
\hline 21 & + & - & - & 1 & & \\
\hline 24 & + & - & - & 1 & & \\
\hline 43 & + & - & - & 1 & & \\
\hline 55 & + & - & + & 0 & $1 \mathrm{a}$ & \\
\hline 73 & + & - & - & 1 & & \\
\hline 82 & + & - & + & & $1 \mathrm{a}$ & \\
\hline
\end{tabular}

Table (4): Campylobacter counts, recovered from broiler carcasses from different Apa Hoird.

\begin{tabular}{|c|c|c|c|c|c|c|c|c|}
\hline Replication & 12 & 15 & 21 & 24 & 43 & 55 & 37 & 82 \\
\hline Mean $\log _{10} \mathrm{cfu} / \mathrm{g}$ of sample & 2.93 & 3.31 & 2.8 & 3.1 & 2.7 & 2.75 & 2.1 & 1.9 \\
\hline
\end{tabular}

Table (5): Results of in vitro sensitivity testing of isolates of $C$. jejuni .

\begin{tabular}{|c|c|c|c|}
\hline Antinicrobial agent & $\begin{array}{c}\text { Disc } \\
\text { potency }\end{array}$ & $\begin{array}{c}\text { Standard sensitivity } \\
\text { zone }\end{array}$ & Susceptibility \\
\hline $\begin{array}{l}\text { Gentamycin } \\
\text { Trimethobrim } \\
\text { Flumequine } \\
\text { Kanamycin } \\
\text { Canbenicillin } \\
\text { Nobiocin } \\
\text { Ampicillin } \\
\text { Colstine } \\
\text { Neomycin } \\
\text { Oxytetracycline }\end{array}$ & $\begin{array}{c}10 \mathrm{ug} \\
1.25+ \\
23.5 \mathrm{ug} \\
30 \mathrm{mg} \\
30 \mathrm{mg} \\
100 \mathrm{mg} \\
30 \mathrm{mg} \\
10 \mathrm{mg} \\
30 \mathrm{mg} \\
30 \mathrm{mg} \\
30 \mathrm{mg}\end{array}$ & $\begin{array}{l}>15<19 \\
>11<15 \\
>13<18 \\
>11<15 \\
>11<13 \\
>15<18 \\
>15<18 \\
>11<13 \\
>13<16 \\
>15<18\end{array}$ & $\begin{array}{l}++t \\
++ \\
++ \\
+ \\
+ \\
- \\
- \\
- \\
- \\
-\end{array}$ \\
\hline
\end{tabular}




\section{REFERENCES}

Adayel, S. A (1093) : Epldemlology of Campylobacter of poultry. M.V.Sc. Thesis. Fac. Vet. Med., Zag. Univ.

Berndtson, O.; Torres, N. 1 . and Tamay, 0. J. (1902): Cholera-llke enterotoxine produced by Campylobacter Jejuni. Lancet Jul. 30 (2): 250-253.

Berrang, M. E.; Buhr, R. J.; Cason, J. A and Dickens, J. A. (2001) : Broller carcass contamination with Campylobacter from feces during Defeathering. J. Food. Prot., 64: 2064 - 2066.

Bradbury, w. C. and Murroe, L. (1985) : Occurrencc of plasmids and antibiotics resistance among $C$. Jejunt and $C$. coll Isolatcd from healthy and diarrhelc animals. $J$. Clin. Microb.. 339-346.

Bryan, F. L. and Doyle, M. P. (1995) : Health risks and consequences of Salmonella and Campylobacter jejunt in raw poultry. J. of Food Prot., 58: 326 - 344.

Byrd, J. A. Corrler, D. E.; Human, M. E.; Balley. R. H.; Stanker. L., H. and Hargls, B. (1988) : Incldence of Campylobaeter in crops of preharvest market age broller chickens. Poultry Sci., 77:1303-1305.

Carter, G. R. (1984) : Dlagnostic Procedures In Veterinary Bacteriology. 4th ed. Charles Thom as. publisher. Spring Reld, Llionls, USA.

Diker, K. S. and Yardimci, H. (1989) : Isolation and characterization of campylobacter specles from chiekens. Veterinerlik ve hayvancllik Dcrgisi. 13 (3) 257-264.

Erzat, M.; Kamel, S. M.; Khalld, M. A and All, N. M. (1991) : Natural and experimental Campylobacteriosis in chickens. Zagaz.lg Vet. Jour., 19: 155-166.

Fletcher, R. D. and Plastridge, w. N.
(1964): Dilference in physlology of vibrlo spp. from chicken and man. Avaln Dis.. 8: 72-75.

Hargls, B. M.; Caldwell, D. J.; Brewer, R. L.: Corrier, D. E. and Deloach, J. R. (1986): Evaluation of the chicken crop as a source of salmonella contamination for broller carcasses. Poultry Scl., 74:1548 - 1552.

Ixat, A. L.: Gardner, F. A: Denton, J. H. and Golan. F. A. (1988): Incldence and level of Campylobacter jejunl in broller processing. Poultry Sct. 67: 1568 - 1572.

Johannessen, G. S.; Johnsen. G.; Oklend M. and Hofshangen. M. (2007) : Enumeration of thererm tolerant Campylobacter spp. from poultry carcasses at the end of the slaughter-line. Lett. Appl. Microblol.. I -5 .

Kotula, K. L. and Pandya, Y. (1895) : Bacterlal contamination of broller chickens before scalding. J. Food Prot.. 58: 1326 1329.

Kwialck, K.; Wojton, B, and 8tern, N. J. (1800) : Prevalence and distribution of Canpylobacter spp., J. Food Protect., 53: 127-130.

Levina, 1. G. (1064) : Vibrionic enterohepatitis of chickens. Veterinariya, Moscow. 41 (3): $20-22$.

Lor, H. (1984) : New extended blotyping seheme for C. Jejunt, C. coll and C. laridis. J. Clin. Microb., 20: 636-640.

Musgrove, M. T.; Cason, J. A.; Fletcher, D. L.; Stern, N. J.; Cox, N. A and Blley, J. 5. (1997): Effect of cloaeal plugging on mlcroblal recovery form partially processed broller. Poultry Scl., 76: 530 - 533.

Nell, S. D.; Campbell, J. N. and Geene. J. A. (1984) : Campylobacter spectes in broller chlckens. Avlan Path. 13: 777 - 785. 
Oosterom, J.; Notermans, S.; Karman, H. and Engels, G. B. (1883) : Origin and prevalenee of Campylobactcr jejune in poultry processing. J. Food Prot., 46: 339 . 334.

Peckham, M. C. (1984) : Avian vibrio Infeetions. In: M.S. Holstad, H.J. Barries, B.W. Calnek, W.M. Reid and H.W. Yoder jr. (eds) Disease of Poultry, $8^{\text {th }}$ Ed. Jowa State Unlv. Press, Anics.

Prescott, J. F, and Bruin, C. W. (1981) : Carrage of $\mathrm{C}$. Jejunl in healthy and dlarrhoelc animals. Amer. Jour. Vet. Res.. 42: 164 - 165.

Rosenquist, H.; Sommer, H. M.; Nielsen, N. L. and Christensen, B. B. (2006): The e[fect of slaughter operations on the contam. ination of chicken carcasses with thermotoleranl Campylobacter. Int. J. Food Microbtol., 108: 226 - 232.
Saleha, A. A: Mead, G. C. and Ibrahim, A L. (1998): Campylobacter jejund In poultry production and processing in relation to public health. World's Poult. Sci. J., 54: 49 - 58.

8mihert, R. M. (1978) : The genus Campylobacter. Ann. Rev. Microbiol., 32: 673-709.

Stem, N. J.: Clavero, M. R.; Balley. J. S.: Cox, N. A and Rohach, M. C. (1995) : Campylobacter spp. in broilers on the farm and after transport. Poult. Scl. 74: 937 941.

White, P. L.; Baker, A R. and Pames, w. 0 . (1897): Strategles to control Salmonella and Campylobacter in raw poultry products. Rev. Scl. Tcch. Off. Int. Eplz., 16: 525 $-541$.

Zeln. E. (1989) : Campylobacter In Upper Egypt. M.V.Sc., Fac. Vet. Med.. Assulte University. 


$$
\begin{aligned}
& \text { اللمخص العهى } \\
& \text { عـــزل الكامبيلوركتر جـرجـرنـاى من لحـــم اللدواجــن } \\
& \text { أحمـد عبدالمبالـت ، أشرف عبدالرحمن محمد الشـافعى ، منى طلعت رسـلان }
\end{aligned}
$$

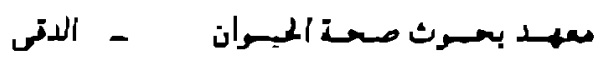

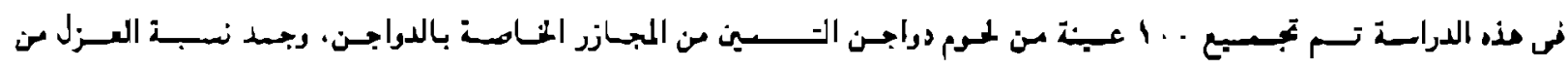

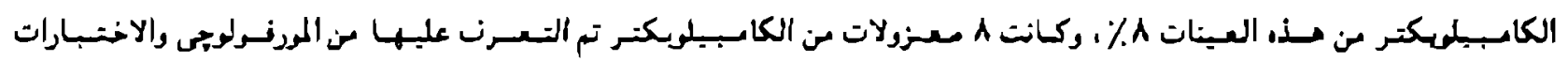

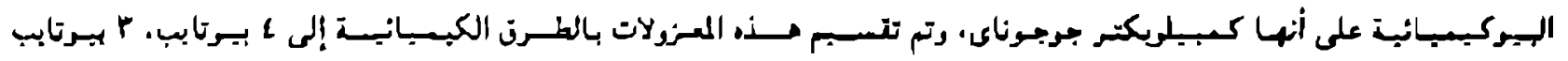

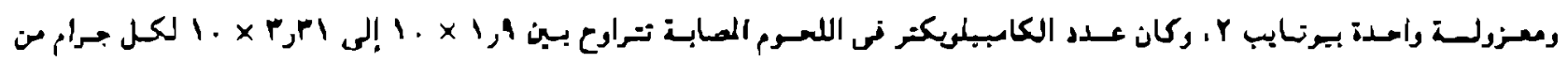
النيسـة.

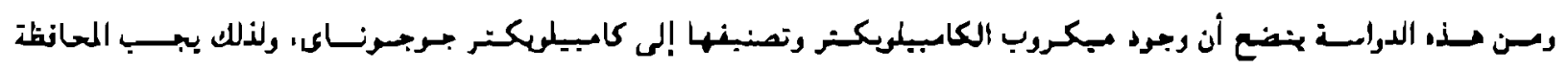

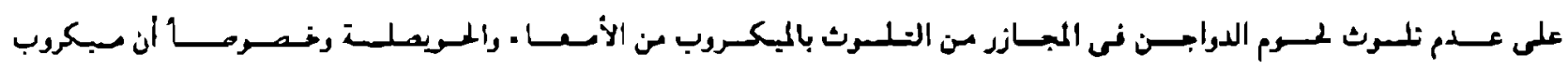

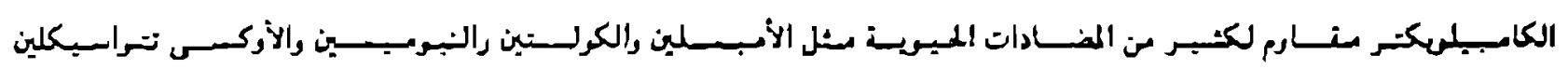

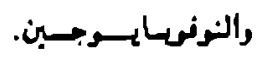

